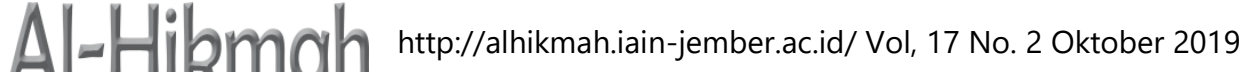 P-ISSN:1907-4328, E-ISSN : 2685-4376/P. 69-78
}

\section{Model Manajemen Strategi Dakwah di Era Kontemporer}

\author{
Sofyan Hadi \\ Institut Agama Islam Neger Jember \\ hadisofy2006@gmail.com
}

\begin{abstract}
The complexity of life is increasing in a sophisticated way. The evolution of human civilization from primitive conditions to being completely technological is a reality that cannot be denied. This is due to talking about a civilization certainly will not be separated from people's lives as a continuous activity. The development of technology directs the activities of life to always look for opportunities behind the crevices of creative thinking piles of each individual. Therefore, the chance of getting these opportunities is getting smaller. Especially if we focus our study in the context of da'wah (an invitation to Islam) which is a noble activity to invite people on the right path according to the religious guidance that God commands through the great prophet Muhammad PBUH and its truth is highly recognized. Therefore, this paper discussed about management strategies that are correlated with Da'wah because preaching with a noble vision will not be successful without good management and strategy.
\end{abstract}

Keywords: Management, Da'wah

\begin{abstract}
Abstrak
Kompleksitas kehidupan meningkat dengan cara yang canggih. Evolusi peradaban manusia dari kondisi primitif menjadi serba berteknologi adalah kenyataan yang tidak bisa dipungkiri. Hal ini disebabkan berbicara tentang suatu peradaban tentu tidak akan lepas dari kehidupan masyarakat sebagai suatu kegiatan yang berkesinambungan. Perkembangan teknologi mengarahkan aktivitas kehidupan untuk selalu mencari peluang di balik celah-celah tumpukan pemikiran kreatif setiap individu. Oleh karena itu, peluang untuk mendapatkan peluang tersebut semakin kecil. Apalagi jika kita memfokuskan kajian kita dalam konteks dakwah yang merupakan kegiatan mulia untuk mengajak manusia ke jalan yang benar sesuai dengan tuntunan agama yang Allah perintahkan melalui nabi besar Muhammad SAW dan kebenarannya sangat tinggi. Oleh karena itu, tulisan ini membahas tentang strategi manajemen yang berkorelasi dengan dakwah karena dakwah dengan visi mulia tidak akan berhasil tanpa manajemen dan strategi yang baik.
\end{abstract}

Kata kunci: Manajemen, Da'wah 


\section{Pendahuluan}

Manajemen strategi adalah seni dan ilmu penyusunan, penerapan, dan pengevaluasian keputusan-keputusan lintas fungsional yang dapat memungkinkan suatu institusi/lembaga/organisasi mencapai sasarannya. Manajemen strategis adalah proses penetapan tujuan organisasi, pengembangan kebijakan dan perencanaan untuk mencapai sasaran tersebut, serta mengalokasikan sumber daya untuk menerapkan kebijakan dan merencanakan pencapaian tujuan organisasi.

Managemen strategi mempunyai tahap-tahap yaitu perumusan, implementasi dan evaluasi yang sangat penting untuk menentukan berhasilnya suatu organisasi atau tidak. Kemudian adanya pengamatan lingkungan eksternal dan internal organisasi untuk menyesuaikan kebijakan apa atau rencana apa yang cocok untuk organisasi tersebut.

Menurut Wheelen dan Hunger, (2011; 56-60) konsep dasar proses manajemen strategis meliputi 4 elemen dasar, yaitu : Pengamatan lingkungan (Environmental Scanning), Perumusan strategi (Strategy Formulation), Implementasi strategi (Strategy Implementation) dan evaluasi dan pengendalian (Evaluation and Control).

Strategi dalam pencapian tujuan organisasi dapat dirumuskan sebelumnya dengan melakukan suatu analisis terhadap keseluruan indikasi dalam organisasi tersebut. Dengan mengadakan analisis maka sang pemimpin mampu menemukan formula (strategi) yang baik untuk mengarahkan seluruh potensi organisasi, guna pencapaian tujuan organisasi. Pemimpin seperti inilah yang cerdas dalam memimpin serta mengarahkan organisasi maju kedepan, dan bukan pada hanya rutinitas organisasi.

Selain itu, kegiatan analisis organisasi juga dapat digunakan dalam pengambilan keputusan dan pemecahan suatu masalah. Dengan menggunakan analisis yang menyeluruh dan tepat, maka sang pemimpin akan tepat dalam mengambil keputusan serta lebih memberdayakan pelaku-pelaku organisasi. Selain itu dalam berbagai masalah dapat diselesaikan dengan tidak mengorbankan orang lain, namun dapat secara lebih bijak memutuskan serta pemecahan lebih pada sumber masalah dan tidak bias.

Menurut Jurgen Hubermas, "dakwah" merupakan media transformasi teori emansipatoris. Artinya, sejauhmana dakwah mampu membantu masyarakat untuk mencapai otonomi dan kedewasaan (mundigkeit) berpikir dan bertindak. Baginya, masyarakat yang reflektif (cerdas) adalah yang berhasil melakukan "komunikasi" yang baik dan memuaskan dengan sesama dalam interaksinya (Hubermas 1965 : Bag. I \& III). Dalam hal ini "pembawa kabar dari langit" (baca:agama) itu hendaknya membuat lawan bicara atau objek yang dihadapinya mampu memahami maksudnya dengan mencapai apa yang disebut "klaim-klaim kesahihan" (validity claim). Dalam pengertian ini, dakwah perlu dirubah bentuk, artinya transformasi 
nilai dari dogma ke aplikasi massa. Sebagai konsekuensinya, dakwah harus mengikuti perkembangan manusia secara terus-menerus.

Masyarakat yang didakwahi bukanlah tipologi masyarakat yang dalam pendekatannya dilakukan kritik lewat revolusi dengan kekerasan, baik itu kekerasan sikap, kekerasan bahasa maupun kekerasan fisik, melainkan lewat argumentasi secara dialetik. Karena rasio manusia pada dasarnya memiliki kemampuan untuk menemukan kendala-kendala yang merintangi perkembangan diri manusia untuk kemudian berusaha mencapai otonomi dan tanggungjawab atau tingkat kedewasaan yang sesungguhnya.

\section{Pembahasan}

\section{Pengertian Manajemen Strategi}

Manajemen strategi adalah seni dan pengetahuan dalam merumuskan, mengimplementasikan, serta mengevaluasi keputusan-keputusan lintas fungsional yang memungkinkan sebuah organisasi untuk mencapai tujuan (Fred R. David, 2011;6). Manajemen strategis berfokus pada proses penetapan tujuan organisasi, pengembangan kebijakan dan perencanaan untuk mencapai sasaran, serta mengalokasikan sumber daya untuk menerapkan kebijakan dan merencanakan pencapaian tujuan organisasi. Manajemen strategis mengkombinasikan aktivitasaktivitas dari berbagai bagian fungsional suatu bisnis untuk mencapai tujuan organisasi.

Berikut ini adalah beberapa pengertian manajemen strategi dari beberapa ahli:

a. Menurut Thomas Wheelen Manajemen strategi adalah serangkaian dari pada keputusan manajerial dan kegiatan-kegiatan yang menentukan keberhasilan perusahaan dalam jangka panjang. Kegiatan tersebut terdiri dari perumusan/perencanaan strategi, pelaksanaan/ implementasi dan evaluasi (Thomas Whellen, 2010: 105).

b. Menurut Bambang Haryadi (2003:3), strategi manajemen adalah suatu proses yang dirancang secara sistematis oleh manajemen untuk merumuskan strategi, menjalankan strategi dan mengevaluasi strategi dalam rangka menyediakan nilai-nilai yang terbaik bagi seluruh pelanggan untuk mewujudkan visi organisasi.

c. Menurut Mulyadi (2001:40), Manajemen strategi adalah suatu proses yang digunakan oleh manajer dan karyawan untuk merumuskan dan mengimplementasikan strategi dalam penyediaan costumer value terbaik untuk mewujudkan visi organisasi.

Berdasarkan beberapa pendapat tersebut, dapat disimpulkan bahwa manajemen strategi adalah seni dan ilmu untuk formulasi, implementasi dan evaluasi keputusan-keputusan yang bersifat lintas fungsional, yang digunakan sebagai panduan tindakan bagi fungsi SDM, pemasaran keuangan, produksi, dan 
lain-lain agar organisasi dapat mencapai tujuannya.

\section{Tujuan Manajemen Strategi}

Menurut Suwandiyanto (2010:02), terdapat empat tujuan manajemen strategi, yaitu:

a. Memberikan arah pencapaian tujuan organisasi/perusahaan

Dalam hal ini, manajer strategi harus mampu menunjukkan kepada semua pihak kemana arah tujuan organisasi/perusahaan. Karena, arah yang jelas akan dapat dijadikan landasan untuk pengendalian dan mengevaluasi keberhasilan.

b. Membantu memikirkan kepentingan berbagai pihak.

Organisasi/perusahaan harus mempertemukan kebutuhan berbagai pihak, pemasok, karyawan, pemegang saham, pihak perbankan, dan masyarakat luas lainnya yang memegang peranan terhadap sukses atau gagalnya perusahaan.

c. Mengantisipasi setiap perubahan kembali secara merata.

Manajemen strategi memungkinkan eksekutif puncak untuk mengantisipasi perubahan dan menyiapkan pedoman dan pengendalian, sehingga dapat memperluas kerangka waktu/berpikir mereka secara perspektif dan memahami kontribusi yang baik untuk hari ini dan hari esok.

d. Berhubungan dengan efisiensi dan efektivitas.

Tanggung jawab seorang manajer bukan hanya mengkonsentrasikan terhadap kemampuan atas kepentingan efisiensi, akan tetapi hendaknya juga mempunyai perhatian yang serius agar bekerja keras melakukan sesuatu secara lebih baik dan efektif.

\section{Model Manajemen Strategi}

Manajemen strategi berawal dari mengidentifikasi visi organisasi yang sudah ada, misi, tujuan, dan strategi adalah titik awal yang logis untuk manajemen strategis karena situasi sekarang perusahaan dan kondisi dapat menghalangi strategi tertentu dan bahkan mungkin mendikte tindakan tertentu. Setiap organisasi memiliki visi, misi, tujuan, dan strategi,bahkan jika unsur-unsur ini tidak sadar dirancang, ditulis, atau dikomunikasikan.

Manajemen strategi memiliki tahapan atau proses yang disusun dan terstruktur dalam bentuk model seperti gambar di bawah ini (David, 2011:15): 


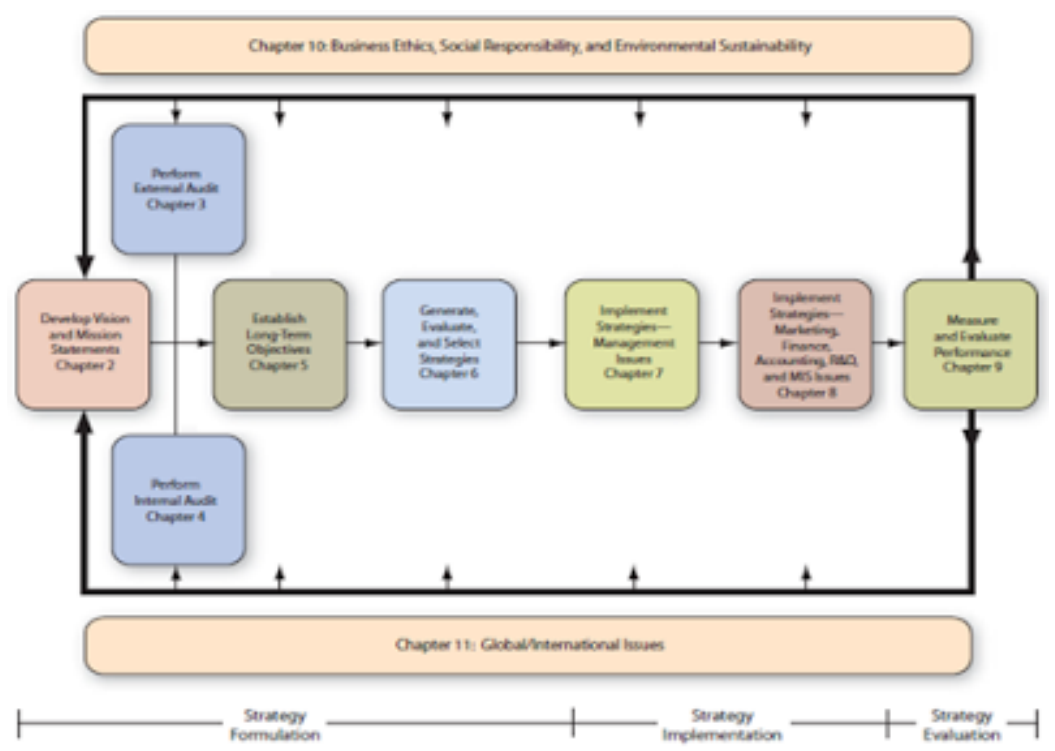

Model Manajemen Strategi

\section{Proses dan Tahapan Manajemen Strategi}

David (2011:6) menjelaskan bahwa proses manajemen strategis terdiri dari tiga tahapan, yaitu :

a. Perumusan Strategi (Strategy Formulation)

Perumusan strategi adalah tahap awal pada manajemen strategi, yang mencakup mengembangkan visi dan misi, mengidentifikasi peluang eksternal organisasi dan ancaman, menentukan kekuatan dan kelemahan internal, menetapkan tujuan jangka panjang, menghasilkan strategi alternatif, dan memilih strategi tertentu untuk mencapai tujuan.

b. Implementasi Strategi (Strategy Implemented)

Implementasi strategi adalah tahap selanjutnya sesudah perumusan strategi yang ditetapkan. Penerapan strategi ini memerlukan suatu keputusan dari pihak yang berwenang dalam mengambil keputusan untuk menetapkan tujuan tahunan, menyusun kebijakan, memotivasi karyawan, dan mengalokasikan sumber daya sehingga strategi yang dirumuskan dapat dilaksanakan. Pada tahap ini dilakukan pengembangan strategi pendukung budaya, merencanakan struktur organisasi yang efektif, mengatur ulang usaha pemasaran yang dilakukan, mempersiapkan budget, mengembangkan dan utilisasi sistem informasi serta menghubungkan kompensasi karyawan terhadap kinerja organisasi.

c. Evaluasi Strategi (Strategy Evaluation)

Evaluasi strategi adalah tahap akhir dalam manajemen strategis. Manajer sangat membutuhkan untuk tahu kapan strategi tertentu tidak bekerja dengan baik; Evaluasi strategi adalah alat utama untuk memperoleh informasi ini. Hal tersebut dapat dilakukan dengan penilaian atau melakukan proses evaluasi 
strategi. Dalam penilaian strategi terdapat tiga aktivitas penilaian yang mendasar, yaitu: Peninjauan ulang faktor-faktor eksternal dan internal yang menjadi landasan bagi strategi saat ini, Pengukuran kinerja, dan 3). Pengambilan langkah korektif. Penilaian strategi sangat diperlukan oleh suatu perusahaan karena strategi yang berhasil untuk saat ini tidak selalu berhasil untuk di masa yang akan datang.

\section{Kontekstualisasi manajemen strategi dengan dakwah di era masa kini.}

Umat Islam memiliki jumlah pengikut terbanyak di Indonesia. Sekitar sembilan puluh persen, ia merupakan bagian yang paling dominan dalam kehidupan masyarakat Indonesia, bersama-sama dengan umat beragama lain mereka hidup berdampingan dan bergaul. Mengadakan kontak sosial di antara mereka, berkomunikasi dan berinteraksi satu sama lain. Dalam proses interaksi tersebut terjadi saling mepengaruhi dan saling bersaing serta berkompetisi satu sama lainnya.

Dalam persaingan tersebut termasuk di dalamnya persaingan dalam menguasai peranan penting di masa depan. Siapapun yang mampu mempersiapkan masa depan dengan baik dan cermat maka ia yang akan menguasai kehidupan masa depan itu, karena ia dengan seksama telah mempersiapkan kader-kader terbaik mereka yang akan berperan dalam kehidupan yang akan datang. Begitu pula sebaliknya siapapun yang mengabaikan masa depan, maka ia akan terpinggirkan dan tidak akan mengambil peran dalam posisi penting di masa yang akan datang. Dakwah yang notabene adalah bagian dari aktivitas dalam mentransformasi pemahaman tentang Islam maka dakwah dirasa penting untuk menggunkan strtegistrategi yang dapat berbaur dengan kondisi masyarakat masa kini.

a. Strategi Dakwah

Strategi pada hakekatnya adalah perencanaan (planning) dan management untuk mencapai suatu tujuan. Tetapi untuk mencpai tujuan tersebut, strategi tidak hanya berfungsi sebagai peta jalan yang hanya menunjukkan arah saja, melainkan harus menunjukkan bagaimana tekhnik (cara) operasionalnya (Sofiatul Iman, 2017: 5)

Dengan demikian strategi dakwah merupakan perpaduan dari perencanaan (planning) dan management dakwah untuk mencapai suatu tujuan. Di dalam mencapai tujuan tersebut strategi dakwah harus dapat menunjukkan bagaimana operasionalnya secara tekhnik (taktik) harus dilakukan, dalam arti kat bahwa pendekatan (approach) bias berbeda sewaktu-waktu bergantung pada situasi dan kondisi.Untuk mantapnya strategi dakwah, maka segala sesuatunya harus dipertautkan dengan komponen-komponen yang merupakan jawaban terhadap pertanyaan dalam rumus Lasswell, yaitu:

$\checkmark$ Who? (Siapa da'i atau penyampai pesan dakwahnya?) 
$\checkmark$ Says What? (Pesan apa yang disampaikan?)

$\checkmark$ In Which Channel? (Media apa yang digunakan?)

$\checkmark$ To Whom? (Siapa Mad'unya atau pendengarnya?)

$\checkmark$ With what Effect? (Efek apa yang diharapkan?

b. Pentingnya Strategi Dakwah

Pentingnya strategi dakwah adalah untuk mencapai tujuan, sedangkan pentingnya suatu tujuan adalah untuk mendapatkan hasil yang diinginkan. Fokus perhatian dari ahli dakwah memang penting untuk ditujukan kepada strategi dakwah, karena berhasil tidaknya kegiatan dakwah secara efektif banyak ditentukan oleh strategi dakwah itu sendiri.

Dengan demikian strategi dakwah, baik secara makro maupun secar mikro mempunyai fungsi ganda, yaitu :

1) Menyebarluaskan pesan-pesan dakwah yang bersifat informative, persuasive dan instruktif secara sistematik kepada sasaran untuk memperoleh hasil optimal.

2) Menjembatani "Cultur Gap" akibat kemudahan diperolehnya dan kemudahan dioperasionalkannya media yang begitu ampuh, yang jika dibiarkan akan merusak nilaii-nilai dan norma-norma agama maupun budaya.

Bahasan ini sifatnya sederhana saja, meskipun demikian diharapkan dapat menggugah perhatian para ahli dakwah dan para calon pendakwah yang sedang atau akan bergerak dalam kegiatan dakwah secara makro, untuk memperdalaminya.

Jika kita sudah tau dan memahami sifat-sifat mad'u, dan tahu pula efek apa yang kita kehendaki dari mereka, memilih cara mana yang kita ambil untuk berdakwah sangatlah penting, karena ini ada kitannya dengan media yang harus kita gunakan. Cara bagaimana kita menyampaikan pesan dakwah tersebut, kita bias mengambil salah satu dari dua tatanan di bawah ini :

1) Dakwah secara tatap muka (face to face)

a) Dipergunakan apabila kita mengharapkan efek perubahan tingkah laku (behavior change) dari mad'u.

b) Sewaktu menyampaikan memerlukan umpan balik langsung (immediate feedback).

c) Dapat saling melihat secara langsung dan bisa mengetahui apakah mad'u memperhatikan kita dan mengerti apa yang kita sampaikan. Sehingga umpan balik tetap menyenangkan kita.

d) Kelemahannya mad'u yang dapat diubah tingkah lakunya relative, sejauh bisa berdialog dengannya.

2) Dakwah melalui media.

a) Pada umumnya banyak digunakan untuk dakwah informatife.

b) Tidak begitu ampuh untuk mengubah tingkah laku.

c) Kelemhannya tidak persuasive 
d) Kelebihannya dapat mencapai mad'u dalam jumlah yang besar

3) Peranan Da'i Dalam Strategi Dakwah

Dalam strategi dakwah peranan dakwah sangatlah penting. Strategi dakwah harus luwes sedemikian rupa sehingga da'i sebagai pelaksana dapat segera mengadakan perubahan apabila ada suatu faktor yang mempengaruhi. Suatu pengaruh yang menghambat proses dakwah bisa datang sewaktu-waktu, lebih-lebih jika proses dakwah berlangsung melalui media.

Menurut konsep A.A Prosedure, bahwa dalam melancarkan komunikasi lebih baik mempergunakan pendekatan, apa yang disebut $A-A$ Proceedure atau From Attention to Action Procedure yang di singkat AIDDA. Lengkapnya adalah sebagai berikut :
a) A_ttention (Perhatian)
b) I_Interest (Minat)
c) D_Desire (Hasrat)
d) D_Decision (keputusan)
e) A_Action (Kegiatan)

\section{Maknanya :}

a) Proses pentahapannya dimulai dengan membangkitkan perhatian (attention). Dalam hal ini pada diri seorang da'i harus menimbulkan daya tarik (source attactiveness).

b) Sikap da'i berusaha menciptakan kesamaan atau menyamakan diri dengan mad'u sehingga menimbulkan simpati mad'u pada da'i.

c) Dalam membangkitkan perhatian hindarkan kemunculan himbauan (appeal) yang negative sehingga menumbuhkan kegelisahan dan rasa takut.

d) Apabila perhatian mad'u telah terbangkitkan, hendaknya disusul dengan upaya menumbuhkan minat (interest) yang merupakan derajat lebih tinggi dari perhatian.

e) Minat adalah kelanjutan dari perhatian yang merupakan titik tolak bagi timbulnya hasrat (desire) untuk melakukan suatu kegiatan yang diharapkan mad'u.

f) Hasrat saja pada diri mad'u belum berarti apa-apa, sebab harus dilanjutkan dengan keputusan (decission), yakni keputusan untuk melakukan kegiatan (action) sebagaimana diharapkan da'i.

Dengan strategi dakwah seorang da'i harus berfikir secara konseptual dan bertindak secara sistematik. Sebab komunikasi tersebut bersifat paradigmatik. Paradigma adalah pola yang mencakup sejumlah komponen yang terkorelasikan secara fungsional untuk mencapai suatu tujuan. Suatu paradigma mengandung tujuan. Dan tujuan pada paradigma tesebut, yakni "mengubah sikap, opini atau pandangan dan perilaku". (to change the attitude, opinion and behavior), sehingga timbul pada diri mad'u efek afektif, efek kognitif, dan efek konatif atau behavioral. 


\section{Kesimpulan}

Manajemen strategi adalah seni dan pengetahuan dalam merumuskan, mengimplementasikan, serta mengevaluasi keputusan-keputusan lintas fungsional yang memungkinkan sebuah organisasi untuk mencapai tujuan. Strategi pada hakekatnya adalah perencanaan (planning) dan management untuk mencapai suatu tujuan. Tetapi untuk mencpai tujuan tersebut, strategi tidak hanya berfungsi sebagai peta jalan yang hanya menunjukkan arah saja, melainkan harus menunjukkan bagaimana tekhnik (cara) operasionalnya.

Terlebih sebagai insan muslim yang memiliki tugas mulia yang disebut dengan dakwah maka startegi sangat dibutuhkan dalam dakwah. Pentingnya strategi dakwah adalah untuk mencapai tujuan, sedangkan pentingnya suatu tujuan adalah untuk mendapatkan hasil yang diinginkan. Dalam strategi dakwah peranan dakwah sangatlah penting. Strategi dakwah harus luwes sedemikian rupa sehingga da'i sebagai pelaksana dapat segera mengadakan perubahan apabila ada suatu faktor yang mempengaruhi. Suatu pengaruh yang menghambat proses dakwah bisa datang sewaktu-waktu, lebih-lebih jika proses dakwah berlangsung melalui media. Dengan strategi dakwah seorang da'i harus berfikir secara konseptual dan bertindak secara sistematik. Sebab komunikasi tersebut bersifat paradigmatik. Paradigma adalah pola yang mencakup sejumlah komponen yang terkorelasikan secara fungsional untuk mencapai suatu tujuan. Suatu paradigma mengandung tujuan. Dan tujuan pada paradigma tesebut, yakni "mengubah sika, opini atau pandangan dan perilaku". (to change the attitude, opinion and behavior), sehingga timbul pada diri mad'u efek afektif, efek kognitif, dan efek konatif atau behavioral.

\section{Daftar Pustaka}

David, Fred R. 2011. Strategic Management Manajemen Strategi Konsep, Edisi 12. Jakarta: Salemba Empat.

Effendy.2003. Onong Uchjana. Ilmu, Teori dan Filsafat Komunikas. Bandung: PT. Citra Aditya Bakti.

Hafidz.2006.Abdullah Cholis, dkk. Dakwah Transformatif. Jakarta: PP LAKPESDAM NU.

Hariadi, Bambang. 2003. Strategi Manajemen. Malang: Banyumedia Publishing.

Iman, Sofiatul. 2017. Proses dan Analisis Manajemen Strategi Dakwah. Makalah (tidak diterbitkan)

Mulyadi. 2001. Akuntansi Manajemen : Konsep, Manfaat dan Rekayasa, Edisi Ketiga. Jakarta: Salemba Empat.

Suwandiyanto, M. 2010. Manajemen Strategi dan Kebijakan Perusahaan. Online Syihata. 1986. Abdullah. Dakwah Islamiyah. Jakarta: Depag.șș̣̦Ș 
Al-Hikmah. Vol, 17 No. 2 Oktober 2019

Wheelen, Thomas L., Hunger, J. David. 2010. Strategic Management and Business Policy Achieving Sustainability. Twelfth Edition. Pearson.

78 H. Sofyan Hadi 